\title{
A critical review of ESP curriculum for pharmacists at SMKN 5 Pangkalpinang, Bangka Belitung
}

\author{
Pratiwi Amelia \\ STKIP Muhammadiyah Bangka Belitung, Jl. KH A Dahlan, Mangkol, Kec. Pangkalan Baru, Kabupaten Bangka Tengah, Kepulauan Bangka Belitung \\ 33684 , Indonesia \\ pratiwi.amelia@stkipmbb.ac.id
}

ARTICLE INFO

Article history

Received 18 December 2019

Revised 9 March 2020

Accepted 23 August 2020

Available Online 15 January 2021

Keywords

ESP

curriculum

pharmacist

\section{ABSTRACT}

This paper presents a critical review of the ESP curriculum for the tenth grade of pharmacists' students at SMKN 5 Pangkalpinang. This critical review is based on the theory of Language Curriculum Design proposed by Nation \& Macalister (Nation \& Macalister, 2007). It is found that the English curriculum, which uses by SMKN 5 Pangkalpinang is not suitable for the students of pharmacists. Teaching English for pharmacists at SMKN 5 Pangkalpinang needs modification and revitalisation to accommodate the needs of the students in the future. The general teaching materials for the students will not fulfil the language skills needed by the students. However, the materials should be specific. The revitalization of ESP curriculum at SMKN 5 Pangkalpinang should be based on research on the environment and need analysis of learning English as pharmacists. It also should consider the principles of curriculum design in teaching English for a specific purpose.

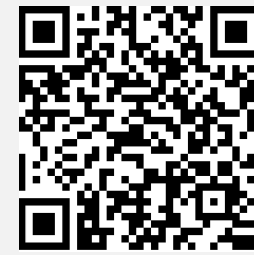

This is an open access article under the CC-BY-SA license.

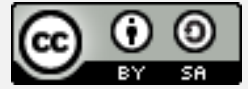

\section{Introduction}

The studies on designing ESP curriculum has started in a few decades. Hutchinson and Waters (1987) proposed the most fundamental concept of ESP, which offers an approach in teaching ESP. This concept is well known and emphasizes/ more on process than product, which processes based on the basis of need analysis. Hutchinson and Waters (1987) present a deep analysis of ESP, which elaborates it into several branches of ELT. They figure out the sub-branches of ESP into more detailed elements in every piece field of knowledge that requires English as needed skills. That is why, nowadays such as the term of English for Science and Technology (EST), English for Business and Economics (EBE), and English for Social Sciences (ESS) are very commonly used by academicians or researchers (Kusni, 2013). Based on this idea, English divides into English for Academic Purposes (EAP) or English for Occupational Purposes (EOP) in relation to the purpose of using it. Furthermore, Paltridge and Starfield also break the sub-branches of ESP areas into more specific field of knowledge such as English for Science and Technology, English in the Workplace, Business English, Legal English, Aviation English, English for Nursing, English for banking, English for Research Publication Purposes, and so on (Paltridge \& Starfield, 2013)

Thus, it can be said that ESP as a branch of ELT has specific goals and characteristics, which differentiates it with other categories in teaching English. The characteristics of ESP are absolute and it has variable characteristics (Dudley-Evans \& John, 1998). The absolute characteristics of ESP 
because it has a specific purpose and it is designed to meet the particular need of the learner without losing the language competence of the students such as grammar, lexis, register, discourse, and genres. They agreed that ESP is designed for a particular subject in specific teaching and learning situations that differ it into the purpose of learning English in general. ESP not only designed for adult learners with specific professional work situations, but it also can be used at a lower level with different level knowledge and skills required.

Basturkmen notices ESP can be used in many ways (Basturkmen, 2006). In addition, Richards also add that ESP stimulates students to develop their English language needs so that they can communicate with a group of people, which has the same purpose in doing communication (Richards, 2001)

Based on the statements above, I strongly believe that teaching ESP is not simple in practice. It is more complicated as we know that there are too many sub-branches of ESP in academic or in professional work, but not all of them support the needs of the learners or the workers specifically. That is why designing ESP materials based on the needs of the students is mandatory, otherwise, what the students get while learning will not meet the demand of their future job.

This paper focuses on the ESP curriculum implemented at SMKN 5 Pangkalpinang. SMKN 5 Pangkalpinang established on October 28, 2011, by Decree of Mayor of Pangkalpinang number 423 the Year 2011. SMKN 5 Pangkalpinang is the only vocational school which has a pharmacists program in Bangka Belitung Province. This school states and elaborates their goal into the vision and mission. The vision of SMKN 5 Pangkalpinang is to build an intelligent, competitive, independent, and good character of human resources in a global context. To gain the vision, SMKN 5 Pangkalpinang elaborates the mission into three points: 1) developing human resources in order to build the developmental sector, providing services in the field of education, 2) improving the quantity, quality, and functionality of infrastructure and 3) fostering the spirit of excellence in science and technology.

Practically, those vision and mission might be achieved through a complete package of the curriculum to reach the learning outcome in each phase of learning which supports the target need in the job market. Based on an interview on May 19, 2019, with English teacher in SMKN 5 Pangkalpinang who teaches English at tenth grade, this school currently implements the 2013 curriculum as guidance in teaching all subjects to each grade in the whole semester. The teachers have many challenges in implementing and developing the ESP course to the students. The challenges are the limitation of time to teach English, limitation sources and low motivation of the students. Also, it was found that the English textbook of the 2013 curriculum provided by the government does not cover the needs of the students in SMKN 5 Pangkalpinang as a pharmacist. However, still, the teachers in SMKN 5 Pangkalpinang use the existing materials provided in the textbook by the government without any modification or adaptation in terms of goals and content of teaching materials. The teachers also never conduct an environment and need analysis before implementing the course. As a consequence, the achievement of the students in the English subject is under expectation.

\section{Research Method}

In order to solve the problem, this study employed qualitative methodology. The research object of this study is the ESP curriculum for pharmacists and the research subjects are the existing curriculum document, teachers, and students at SMK N 5 Pangkalpinang. The data were collected through document observation, school observation, and interview. The ESP curriculum document was observed thoroughly, and some parts are highlighted to be connected to the results of the classroom observation and the interviews. The interviews were done to the teachers and students of SMKN 5 Pangkalpinang to enable the critical review toward the ESP curriculum document used in the school. After the data were collected, the analysis was done by interpreting and connecting the results of observations and interviews comprehensively and critically.

\section{Findings and Discussion}

Many teachers work in a situation where they do not give specific attention to what and how the students learn the language in the future or how the students will use the language they learned from 
schools. It is a common problem since the centre of learning usually only focuses on the curriculum, the materials, and the assessment (Paltridge \& Starfield, 2013). Actually, the teachers are able to negotiate on determining the goals and all other aspects in a course with learners (Boon, 2011; Clarke, 1991). In other situations, the teachers do not have a chance to modify their curriculum because their environment does not support them to make a modification or the teachers have difficulties to find materials because of the limitation of the teaching materials. This situation often happens in teaching English to specific purposes in vocational schools. This produces problems because usually vocational schools only provide general materials for the students.

However, teaching English for pharmacists at SMKN 5 Pangkalpinang should be able to cope with the language demand of the students. They should be trained to communicate in English by using the appropriate expressions or utterances related to a particular topic related to their field. It hoped that they would have the knowledge and improve their skills, particularly in communicating in English, which is very fundamental to their professional work. Without being trained to practice, the students will have difficulties communicating with others in English. That is why; SMKN 5 Pangkalpinang must facilitate and provide the students with chances to improve their English optimally in the scope of the pharmacy industry.

In designing an ESP course, a needs analysis should only focus on what the learners know in learning already and what they need to know toward learning English in relation to their professional work. Needs analysis could be seen from what the target needs in their target situation, and what the learning needs to do in order to learn the target language (Hutchinson \& Waters, 1987, Fatimah, 2018).

There are some points found in the target needs, particularly the students' needs on the pharmacist program in SMKN 5 Pangkalpinang. First, referring to the vision and mission of SMKN 5 Pangkalpinang, particularly by focusing on produces competent graduates, means that the school should provide knowledge and skills to the students through the course so that they can improve their skills based on the expected competencies, and be a ready-to-work-as pharmacist. Dealing with those points, in order to improve their skills, the students are expected to be competent in the area of pharmacists both spoken and written forms. The ability to communicate to others in English becomes the fundamental need, primarily to fulfil national or international labour markets. That is why this point should be highlighted in providing and fulfilling the students' needs during their study.

Second, considering the syllabuses of English stated in the 2013 curriculum, the content of the English courses in each semester has not fulfilled the vocational school students' needs in terms of a pharmacist. It is because the 2013 curriculum focused on teaching English in general so that it does not cover the needs of the students in the pharmacy industry. However, during semesters, the students are not provided with enough gambits, chunks, and formulaic competence, which are very important to support their career later. Consequently, after completing the whole semester, and even when the students graduate from SMKN 5 Pangkalpinang, they still cannot communicate well in English.

Third, to fulfil the national and international labour markets, the students must be provided with adequate knowledge and skills, which support their career as pharmacists. The students are required to be able to use English communicatively both written and spoken. In this case, the study program, especially the lecturer who teaches the students, should provide the basic needs to them to communicate in a daily conversation between pharmacist and patient, pharmacist to the doctor, pharmacist to pharmacist, and so on. So, teaching English for pharmacist programs should not only be offered to students in order to pass the national exam, but the main focus should be on the students' communicative competence. That is why the materials designed should cover the communicative events presents in the pharmacy contexts.

Besides that, another aspect that should be taken into account when designing curriculum is environment analysis. It involves some consideration of the situation, which might influence the teaching and learning situation. Environment analysis is important to know what factors that will have a strong effect of the course. These factors can derive from the learners, the teachers, the environment situation presented in schools, also the environmental analysis is possible comes from outside the classroom such as the influence from society or stakeholders which correlates with schools activity. Dealing with those factors, it found that there is minimal class time and contact 
time with English. Based on the 2013 curriculum, the students only learn English three hours a week. Consequently, the English teachers in SMKN 5 Pangkalpinang do not have enough time to deliver all of the course materials to the students.

Furthermore, the students of pharmacists program in SMKN 5 Pangkalpinang should fulfil fieldwork in the drugstore for three months. While during fieldwork, the students will not attend the course in class, they will only focus on their fieldwork. In other words, the students will only learn English effectively in the tenth grades for about two semesters until they graduate from SMKN 5 Pangkalpinang. Meanwhile, to fulfil the learning goal, the teachers should teach the entire course in the textbook. This limitation makes the teachers unable to teach all of the materials. As a consequence, the teachers skip some of the teaching materials and jump into the next content in the textbook. Also, the teachers do not have enough time to prepare the course materials. The teachers are too busy with administrative and management tasks in school. Also, the teachers are busy preparing the simulation for the national exam, trying out, and the national exam. As a consequence, the learning activity in the school will not be effective.

MoNE Number 330/D.D5/KEP/KR/2017 states that the objectives of the curriculum in the vocational school for pharmacists include four aspects of competence, namely spiritual competence, social competence, knowledge competence, and skills through the learning process. The aims of competence in the aspect of knowledge is to apply, analyse, and evaluate factual, conceptual, procedural, and metacognitive knowledge in the scope of English studies at the technical, specific, and detailed level. The aims of competence in the aspect of skills is to carry out specific tasks using tools, information, and work procedures in the field of English studies; they demonstrate skills of processing, and presenting effectively, creatively, productively, critically, independently, collaboratively, and communicatively. These competencies are the strengths of the 2013 curriculum if it compared to the previous curriculum (KTSP Curriculum). However, the syllabus does not cover the need for the students in pharmacists because the orientation of learning is still general English.

The purpose of communicative teaching is to enhance the students' knowledge and skills to explore all the language competence in order to make effective communication (Nation \& Macalister, 2010). Students should be able to use language to use, share, and give information purposely. So, the goal of teaching ESP for pharmacists students should be in order to make the students able to communicate in a business or work situation. Dealing with this goal, the ESP curriculum of pharmacists should develop the language needed in the context of drug discovery and drug development and develop vocabularies which are used in the pharmacist's industry. In language development, the ESP course in pharmacists should provide the students with grammar clinic, tense review, vocabulary building, reading, and building listening skills through discussion, role-play, presentations, individual feedback, and so forth.

\section{Conclusion}

The ESP curriculum requires modification and adaptation in order to accommodate the needs of each of the sectors in a vocational school. The English curriculum, which is used by SMKN 5 Pangkalpinang, is not suitable for the students of pharmacists. Hence, it needs revitalization on the ESP curriculum for pharmacists in order to fulfil their career in the labour market. The revitalization should be based on research on the environment and need analysis of learning English and consider the principles of curriculum design in teaching English for a specific purpose.

\section{References}

Basturkmen, H. (2006). Ideas and options in English for specific purposes. London: Mahwah, New Jersey.

Boon, A. (2011). Negotiated syllabuses: Do you want to? In J. Macalister \& I. S. P. Nation (Eds.), Case studies in language curriculum design: Concepts and approaches in action around the world, 166-177. New York, NY: Routledge/Taylor \& Francis.

Clarke, D. F. (1991). The negotiated syllabus: What is it and how is it likely to work? Applied Linguistics, 12 (1), 13-28. 
Dudley-Evans, T. and M. J. St. John. (1998). Developments in English for specific purposes: A multidisciplinary approach. Cambridge: Cambridge University Press.

Fatimah, N. (2018). Students' needs for academic writing at the English education department. English Language Teaching Educational Journal, 1(3), 161-75.

Hutchinson, T., \& Waters, A. (1987). English for specific purposes: A Learning-centred approach. Cambridge: Cambridge University Press.

Kusni. (2013). Reformulating English for Specific Purposes (ESP) in Indonesia: Current issues and future prospects. SELT 2013. Proceeding, ISBN: 978-602-17017-1-3

Nation, I. S. P. \& Macalister, J. (2007). Language curriculum design (2nd ed). ELI Occasional Publication 23. Wellington: School of Linguistics and Applied Language Studies, Victoria University of Wellington

Nation, I. S. P. \& Macalister, J. (2010). Language curriculum design. New York \& London: Routledge.

Paltridge, B., \& Starfield, S (Eds.). (2013). The handbook of English for specific purposes. West Sussex: Wiley-Blackwell.

Paltridge, B., \& Starfield, S. (2013). The handbook of English for specific purposes. West Sussex, UK: John Wiley \& Sons.

Richards, J. C. (2001). Curriculum development in language teaching. Cambridge, UK: Cambridge University Press. 